\title{
The Patronage Behaviour of Islamic Bank's Customers: Empirical Studies in Aceh
}

\author{
M. Shabri Abd. Majid, Said Zulhanizar
}

\begin{abstract}
The Patronage Behaviour of Islamic Bank's Customers: Empirical Studies in Aceh. This study is aimed at empirically exploring the pertinent factors, which customers and non-customer perceive as germane to their selection of Islamic bank in Aceh, Indonesia. A sample of 300 customers and non-customer of Bank Aceh Syariah were selected based on the convenience sampling technique. Using the logistic regression technique, the study documented that the customers' selection of the banks were influenced by the factors of banks' characteristic, services and trust, shariah compliance, and physical objects. Of these factors, banks' characteristic and shariah compliance were found to be the most pertinent factors perceived by the customers and non-customer to their selection of Islamic bank in Aceh, Indonesia. These findings imply that to attract more customers, the Islamic bank should enhance their unique characteristics and products' compliance.
\end{abstract}

Keywords: customer preferences; patronage behaviour; Islamic banking; logistic regression

\begin{abstract}
Abstrak. Perilaku Pemilihan Oleh Nasabah Bank Syariah: Studi Empiris di Aceh. Penelitian ini bertujuan untuk mengeksplorasi secara empiris faktor yang mempengaruhi nasabah dalam memilih bank syariah di Aceh, Indonesia. Sebanyak 300 nasabah dan non-nasabah Bank Aceh Syariah dipilih berdasarkan teknik convenience sampling, dan datanya dianalisis dengan menggunakan teknik regresi logistik. Hasil penelitian menemukan bahwa pemilihan bank syariah dipengaruhi oleh faktor karakteristik bank, pelayanan dan kepercayaan, kepatuhan syariah, dan faktor fisik perbankan. Bank karakteristik dan kepatuhan syariah kepatuhan merupakan faktor yang paling menentukan nasabah dalam memilih bank syariah di Aceh, Indonesia. Temuan ini berimplikasi bahwa untuk menarik lebih banyak nasabah, bank syariah harus meningkatkan keunikan karakteristik mereka dan kepatuhan syariah dari produk yang mereka tawarkan sekaligus operasionalnya.
\end{abstract}

Kata kunci: preferensi nasabah; perilaku pemilihan; perbankan syariah; regresi logistik 


\section{Introduction}

In recent years, the development of Islamic banking and financial services industry has experienced a very rapid progress worldwide. Islamic banking industry in Indonesia has also recording similar patterns. This progressive development of Islamic banking industry is due to the advancements in information and communication technology, prudent banking deregulation, and the public awareness on the importance of having transaction based on the Shari'ah. The policy of financial deregulation led to a new phenomenon that resulted in an aggressive competition among banks, including the competition between the conventional banks and Islamic banks. The competition among the banks affects the growth of banks, and vice versa. The banks with a higher growth rate could easily win the competition due their higher capability and good management. The growth of the banks is strongly influenced by their ability to raise funds from the public, both in small and large scales. Without having sufficient funds, the bank would not be able to provide financing to generate profits.

Statistically, a total of funds of the banks in Indonesia either from the internal sources and funds derived from accumulated profits, which are reinvested in the banks, amounted to only 8-9\% of the total assets. Banks in Indonesia at larger, and banks in Aceh in particular, their average amount of owned capital and reserves have never exceeded $5 \%$ of total assets. This means that most of the banks' capital comes from other financial institutions, loans from the Central Bank and the greatest portion of the funds from public. Therefore, it is not surprising that all banks, both conventional and Islamic banks engage in an aggressive competition to attract public funds by using various marketing strategies, such as promotion through mass media and electronic, prizes offering, lucrative profit-sharing ratios, lower interest rates campaigns.

Likewise, the Islamic banks in Indonesia, the Islamic banking fund raising activities in the province of Aceh alone has increased quite rapidly during the period of 2011. As of the end of the period 2011, the Islamic banking deposits increased by $45.89 \%$ over the previous year. Funds from the public occurred in all components, i.e., checking accounts increases by $29.42 \%$, savings increases $46.51 \%$, and deposits increases by $83.5 \%$. The rapid growth in deposits coming from the public last few years provides an indication of the positive response of the Acehnese to the Islamic banking.

The development of Islamic banking industry in Indonesia at large, and in Aceh in particular, is generally quite encouraging. Islamic Bank, which operated the first time in Indonesia in 1992, has contributed positively to the development of banking industry in Indonesia. The presence of Islamic banks offers for public an 
alternative to choose Islamic Banks for their transactions on the basis of Shariah, which are usury-free (riba-free), uncertainty-free (gharar-free), and gambling-free (maysir-free). The promising growth of Islamic banking industry in Indonesia, it is certainly cannot be separated from the government's drive to provide a prudent regulation and conducive environment for the Islamic banks to continuously grow in Indonesia. Similar to the development of Islamic banks in Indonesia, the growth of Islamic banking industry in the province of Aceh was also very encouraging. The increasing number of full-fledged Islamic banks and commercial banks characterizes it with Shari'ah business unit (Islamic window) that operates in Aceh. The presence of Islamic banks in Aceh would provide an opportunity for people to choose and get excellent services from the banks that offers Islamic banking services. Based on the reports of Bank Indonesia as of December 2011, there have been 10 Islamic banks operating in Aceh, namely: Bank Muamalat, Bank Syariah Mandiri, Bank Aceh Syariah, Bank Danamon Syariah, Bank Permata Syariah, Bank BRI Syariah, Bank BNI Syariah, Bank BII Syariah Bank Syariah Mega Indonesia and Bank CIMB Niaga Syariah.

Bank Aceh, as a bank owned by the Government of Aceh are not left behind in providing Islamic banking services to the Acehnese by opening his first Shari'ah branch (Islamic window) in the city of Banda Aceh in 2004, exactly one month before the earthquake and tsunami hit hardly the province. By the grace of Allah, and hard working of the staff as well as strong support from the public and the local government, the growth of Bank Aceh Syariah today has been pretty encouraging. Hitherto, Bank Aceh Syariah has 25 branches in the entire Aceh, and Bank Aceh Syariah Branch Office of Sigli is one of them, which started its operation on April 22, 2009 and show a promising growth. Table 1 below show the development of Bank Syariah Aceh Branch of Sigli, as follows:

Table 1. Selected Indicators of Bank Aceh Syariah, Branch Office of Sigli, Aceh (in Million IDR)

\begin{tabular}{lcccccccc}
\hline \multicolumn{1}{c}{ Indicator } & $\mathbf{2 0 1 1}$ & $\begin{array}{c}\text { Growth } \\
\text { (\%) }\end{array}$ & $\mathbf{2 0 1 2}$ & $\begin{array}{c}\text { Growth } \\
\text { (\%) }\end{array}$ & $\mathbf{2 0 1 3}$ & $\begin{array}{c}\text { Growth } \\
\text { (\%) }\end{array}$ & \multicolumn{2}{c}{ Mean } \\
\hline Assets & 66,371 & 164 & 74,371 & 112 & 92,916 & 125 & 68,546 & 134 \\
Financing & 65,277 & 167 & 73,038 & 112 & 91,413 & 125 & 67,194 & 135 \\
Deposits & 17,042 & 109 & 25,235 & 148 & 55,590 & 220 & 28,368 & 159 \\
Profit & 1,252 & 219 & 2,033 & 162 & 3,305 & 163 & 1,790 & 181 \\
Number of Customers & 1,113 & 88 & 933 & 84 & 4,422 & 474 & 1,933 & 215 \\
\hline
\end{tabular}

Source: Annual Report, Bank Aceh Syariah (2010 - 2013) 
Table 1 shows that the Bank Aceh Syariah, Branch Office of Sigli with the following five indicators: assets, financing, third party funds, profit and customer numbers continue to experience significant growth rates every year. During the 2010-2013 period, the bank's total assets, on the average, has increased by $134 \%$, total financing by $135 \%$, total deposits by $181 \%$, and total customers by $215 \%$. One of the factors contributing to this promising growth of the bank is due to the increasing disbelief of the Aceh's community to the conventional banks, which are operating against the shari'ah principles. With increasing competition in the banking industry today, the Islamic banks have to really know the right strategy to win the competition. Therefore, in order to improve operational performance, Islamic banking seeks to serve the needs of the people of Aceh. In general, a bank's customer would select a bank that could provide higher benefits, convenient transactions, better services, and shari'ah compliant products. In selecting the banks, customers would consider certain factors of the banks such as the characteristics of banks, banks' trust services, shari'ah compliance products, and services, and the physical object of the banks.

\section{Literature Review}

Previous studies on the Islamic banks' preferences have been intensively conducted in Malaysia (Haron at al., 1994; Amin and Isa, 2008; Dusuki and Abdullah, 2007; Abdelghani and Oladokun, 2012, Haque et al., 2009), Jordan (Erol and El-Bdour, 1989, Kamal et al., 1999), Bangladesh (Hassan et al., 2007), Bahrain (Al-Ajmi et al., 2009), Thailand (Lateh et al., 2009), and UK (Walid et al., 2010). Similar studies have also been conducted in the Indonesia (Anam, 2006; Efendi, 2008; Maski, 2010). Anam (2006) investigated the influences of psychological and rational factors on the customer's decision to save their money at the Bank Syariah Mandiri, Branch Office of Pamekasan using multiple regression analysis. These factors were found to be the significant factors affecting the customers' decision. In his study on the customer's preferences of the Bank Muamalat Malang using multiple regression technique, Efendi (2009) found that the level of education, family responsibilities and bank services were the dominant factors influencing the customer's decision. Using a logistic regression analysis, Maski (2010) found that bank's characteristics, bank's services and trust, and bank's physical objects affecting the Islamic bank customer's decision in Malang. Finally, Misbach and Hadiwidjojo (2013) empirically explored factors affecting the Islamic bank' customers in Makassar, and found that bank's services quality and trust had positively influenced their bank's customers decision.

Additionally, Hidayat et al. (2015) examined the effects of service quality, 
customer trust and customer religious commitment on customers' satisfaction and loyalty of 150 customers of Islamic banks in East Java using the Structural Equation Modelling (SEM). They found that service quality and customer trust affected both directly and indirectly the customer loyalty mediated by satisfaction of Islamic banks' customers. However, the customer religious commitment has no direct and indirect effects on the customers' satisfaction and loyalty. Suryani and Hendryadi (2005) examined the relationships among satisfaction, word of mouth (WOM) and loyalty of 235 Islamic bank's customers in Lhokseumawe, North Aceh using the Partial Least Square (PLS) technique. They found that the quality of service dimensions of service portfolio and assurance and the reliability of communication were the most dominant factors affecting satisfaction. The satisfaction was found to significantly affect the word of mouth and loyalty. Finally, using a factor analysis, Suryani (2014) identified factors forming quality of service in PT. Bank Muamalat Indonesia, Tbk Branch of Medan, North Sumatera. She found that quality of communication was the most dominant factor explaining service quality, followed by the factors product innovation and physical aspects.

The above-reviewed studies have investigated factors affecting the banks' customer preferences, but most of them did not incorporate in their analysis the shari'ah compliant factor of the Islamic banks in attracting the customers. The operationalisation of Islamic banks is different to the conventional banks, particularly in terms of their offering products and services that are in harmony with the shariah. Thus, investigating the customers' preferences on the Islamic banks should include the shari'ah compliant components. Additionally, none of the previous studies investigated the factors affecting customers' choice of Islamic bank using the logistic regression approach, as our study. The logistic regression is a better able model to exactly identify the decision of customers to either select or not select the Islamic banks. Thus, this study tries to fill the existing gaps in the literature on Islamic banking preferences by attempting to empirically explore the effects of bank's characteristics, services and trust, physical objects, and shari'ah compliant products and services on the customers' preferences to select the bank, with a case of the study of the Bank Aceh Syariah, Branch of Sigli, Aceh. In addition, this study use the logistic regression analysis to the study the bank customer's preferences, as this technique of analysis is the standardized method for this type of analysis. Unlike other previous studies, this study selected both Islamic and conventional banks' customers so that the motivation of choosing the Islamic banks by them could be exactly estimated. The findings of the study are hoped to shed some lights for the banking industry to focus on, particularly in attracting more customers, and potential bank customers in selecting banking products and services. 


\section{Methods}

In Indonesia, Islamic banks have been defined as the bank, which operates its business activities based on Shari'ah principles (Law No. 21, 2008), which are free from elements of riba, maysir, gharar, haram, and zulm. The Islamic bank activities should promote the basic purposes of shari'ah (Maqashid as-Shari'ah), i.e., to protect five essential things: religion (ad-Din); life (an-Nafs); intellectual (al-'Aql); lineage (an-Nasl); and wealth (al-Mal). Thus, the Islamic banks should offer products and services based on the Islamic principles and promote the Maqashid Shariah. This study empirically explores the influences of bank's characteristics, services and trusts, physical objects, and shari'ah compliance of Bank Aceh Syariah, Branch office of Sigli on the customer's preferences to select the bank.

Out of 4,422 customers of the Bank Aceh Syariah, Branch Office of Sigli in 2013, this study only selected 150 of them based on the simple random techniques to be analysed using the logistic regression analysis. In order to have a comprehensive picture of the customer preferences of selecting banks, the study also selected 150 non-Islamic bank customers in the research area, thus making the total of sample amounted to 300 respondents. The number of respondents selected in this study which are more than 100 respondents suggested by Hair et al. (2006: 98-99) are sufficient enough to represent the entire population.

Questionnaire consisting 16-closed question were distributed to the entire respondents. One questions was asked about customer decision either to select or do not select Islamic bank, three questions were asked pertaining to the bank's characteristics, and four questions were respectively asked relating to the bank's trust and services, shari'ah compliance and physical objects. Table 2 provides the operationalisation of the investigated variables.

Before the indicators are further measured and analysed, the validity and reliability tests were conducted to ensure the accuracy and consistency of the data. In addition, the classical assumptions of normality, multicollinearity, and heteroscedasticity were also tested using the standard techniques.

After these instruments and classical assumption were tested, the measured variables would be analysed using the following logistic regression:

$$
\log (P / 1-p)=\beta_{0}+\beta_{1} X_{1}+\beta_{2} X_{2}+\beta_{3} X_{3}+\beta_{4} X_{4}
$$

Where $\mathrm{p}$ is the probability that $\mathrm{Y}$ is equal to 1 , and $\mathrm{X}_{1}, \mathrm{X}_{2}, \mathrm{X}_{3}, \mathrm{X}_{4}$ are the independent variables, and $\beta_{s}$ is the estimated regression coefficients. Logistic regression will form the predictor variable/response $(\log (p /(1-p))$, which is a linear combination of the independent variables. Value of predictor variables is then transformed into a 
probability with logistic function, so that the logistic model in this can be re-written as follows:

$$
\mathrm{CD}=\beta_{1} \mathrm{BC}+\beta_{2} \mathrm{ST}+\beta_{3} \mathrm{SC}+\beta_{4} \mathrm{PO}+\mathrm{e}
$$

where $\mathrm{CP}$ is the customer decision; $\mathrm{BC}$ is the bank characteristics, $\mathrm{ST}$ is the services and trust, SC is the shari'ah compliance, PO is the physical object; and e is the error term.

Table 2. Operationalisation of the Variables

\begin{tabular}{|c|c|c|c|c|}
\hline No & Variable & Definition & Indicator & $\begin{array}{l}\text { Measurement } \\
\text { Scale }\end{array}$ \\
\hline 1. & Customer Decision & $\begin{array}{l}\text { Customer decision to } \\
\text { select or do not select the } \\
\text { Islamic bank }\end{array}$ & $\begin{array}{l}\text { a. Select } \\
\text { b Do not select }\end{array}$ & $0-1$ (Nominal) \\
\hline 2. & Bank Characteristics & $\begin{array}{l}\text { The operation of the bank } \\
\text { and products offered is } \\
\text { based on the profit-loss } \\
\text { sharing principles (Ikatan } \\
\text { Akuntan Indonesia, 2004). }\end{array}$ & $\begin{array}{l}\text { a. Observing the rinciples } \\
\text { of shari'ah } \\
\text { b. Islamic-based products } \\
\text { c. Profit-loss sharing basis }\end{array}$ & $\begin{array}{c}1-5 \\
\text { (Interval) }\end{array}$ \\
\hline 3. & Services and Trust & $\begin{array}{l}\text { Ability to provide the } \\
\text { promised services accurately } \\
\text { and reliably. Ease in } \\
\text { establishing relationships, } \\
\text { good communication, } \\
\text { personal attention, and } \\
\text { understanding of the } \\
\text { individual needs of the } \\
\text { customer (Tjiptono, 2005). }\end{array}$ & $\begin{array}{l}\text { a. Latest info on products } \\
\text { and services } \\
\text { b. Trust and confidence } \\
\text { c. Quality of services } \\
\text { d. Friendly } \& \\
\text { comfortable services }\end{array}$ & $\begin{array}{c}1-5 \\
\text { (Interval) }\end{array}$ \\
\hline 4. & Shari'ah Compliance & $\begin{array}{l}\text { The assurance of the } \\
\text { Islamic banks to provide } \\
\text { products and services } \\
\text { comply with the Islamic } \\
\text { tenets banks (Elias, 2004) }\end{array}$ & $\begin{array}{l}\text { a. Promised services } \\
\text { b. Use of contracts } \\
\text { c. Shari'ah principle } \\
\text { d. Shari'ah Operational } \\
\text { basis }\end{array}$ & $\begin{array}{c}1-5 \\
\text { (Interval) }\end{array}$ \\
\hline 5. & Physical Object & $\begin{array}{l}\text { Physical facilities, } \\
\text { equipment, personnel and } \\
\text { means of communication of } \\
\text { the banks (Tjiptono, 2005) }\end{array}$ & $\begin{array}{l}\text { a. Strategic location } \\
\text { b. Physical attractiveness } \\
\text { c. Computer, ATM, and } \\
\text { phone } \\
\text { d. Personnel appearances }\end{array}$ & $\begin{array}{c}1-5 \\
\text { (Interval) }\end{array}$ \\
\hline
\end{tabular}

\section{Result and Discussion}

At the national level, Bank Muamalat Indonesia (BMI) is the first Islamic bank in Indonesia, which was established in 1991. The Bank BPD Aceh, which is now renamed Bank Aceh has established the shari'ah Unit (Islamic window) on December 28, 2001 by the Decree of Board of Directors No. 047/DIR/HR/XII/ 2001, while officially it was launched on November 5, 2004. Bank Aceh Syariah Branch Office of Sigli is one of 25 branch offices opened in the entire Aceh that started its operation on Tuesday April 22, 2009. 150 customers of the Bank Aceh Syariah 
and conventional banks in Aceh, respectively were investigated their preferences. Based on the respondents' characteristics, most of them were male (54\%), with ages $20-30$ years old (32\%), government employees (39\%), university graduates $(36 \%)$, and income level of IDR 3,5 million. Table 3 provides the respondents perception on the variables investigated.

Table 3. Respondents' Perception

\begin{tabular}{lcccc}
\hline \multicolumn{1}{c}{ Variable } & Minimum & Maximum & Mean & Standard Deviation \\
\hline Bank's Characteristics & 2 & 5 & 3.86 & 0.750 \\
Services and Trust & 3 & 5 & 4.21 & 0.631 \\
Shari'ah Compliance & 2 & 5 & 3.96 & 0.704 \\
Physical Object & 2 & 5 & 4.24 & 0.533 \\
\hline
\end{tabular}

Table 3 shows that the respondents perceived the physical object and services and trust of the bank were, respectively, "good enough" with the average score of 4.21 and 4.24. Meanwhile, the bank's characteristics, and shari' ah compliance was perceived to be "fair" by the respondents with the average score of 3.86 and 3.96, respectively.

As mentioned in earlier section, the instruments testing of validity and reliability as well as the classical assumptions were conducted in the study. However, due to the limited space of the paper, the findings of these tests were not reported here. However, their findings are available with authors upon request. The study found that all instruments were valid and reliable and all variables fulfilled the classical assumptions of normality, non-multicollinearity, and homoscedasticity. Passing all these tests, then study continues investigating the effects of bank's characteristics, services and trust, shari'ah compliance and physical object on the banks' customers' preferences in selecting the banks. Table 4 reports the findings from the logistic regression analysis.

Table 4. Findings of Logistic Regression Analysis

\begin{tabular}{lcccc}
\hline \multicolumn{1}{c}{ Variable } & B & Standard Error & Wald & P-value \\
\hline Bank's Characteristics & 1.785 & 0.388 & 20.638 & 0.000 \\
Services and Trust & 0.205 & 0.389 & 0.225 & 0.636 \\
Shari'ah Compliance & 0.492 & 0.412 & 1.308 & 0.049 \\
Physical Object & 0.259 & 0.334 & 0.508 & 0.476 \\
\hline \multicolumn{1}{c}{-2 Log Likelihood } & Cox \& Snell R Square & \multicolumn{2}{c}{ Nagelkerke R Square } \\
213.565 & \multicolumn{3}{c}{0.273} & 0.364 \\
\hline
\end{tabular}


As shown in Table 4, out of 4 independent variables, only bank's characteristic and shari'ah compliance have significant effects on the Islamic banks' customer preferences. Specifically, the results of this study indicated that the characteristics of the bank have a positive impact to the customer's decision to select the bank at $1 \%$ level of significance. This implies that the characteristics of the bank are closely related to the application of Islamic principles as the true in Islamic bank, finding similar to study by Maski (2010). In selecting the bank, a prospective customer would observe the characteristics of anything that stands out on the bank and the uniqueness of the products offered. Thus, to attract more customers, the Islamic banks should continue maintaining and even improving their unique characteristics as the Islamic bank. Another variable that has significant effect on the banks' customer preferences was the shari'ah compliance of the bank. The positive impact of the shari'ah compliance of the bank could partially due to the profit-sharing practices, services rendered, the contract (agreement) adopted, and bank's operations have been run in accordance with the Islamic principles. Solid and prudent banking regulations ensure the adherence of the Islamic bank to shariah principles and ease the customers to decide which bank to choose for their business partner. Shariah compliance is a manifestation of the fulfilment of all Islamic principles in an institution that has a strong characteristics, integrity, and credibility. Where the compliance culture is values, behaviours and actions, which support the creation of Islamic banks compliance itself. This finding shows that Islamic banks should continue maintaining their operation to be compliance to the shariah principles so that Islamic banks become the preferred bank of Muslims.

Unlike the bank's characteristics and shariah compliance, the services and trust, and the physical object of the bank have no significant influences on the customer's preferences in selecting the bank. This could be, inter alia, due to the customers' attraction to shari'ah compliances of the bank. As long as the bank is, operating based on the Islamic tenets; customers pay no attention on the services, and trust provided by the banks as well as the strategic location of the banks. Customers are more interested in the characteristics of the banks themselves that adopted the Islamic principles in their operation. Islamic banks have tremendous advantages over other financial banks, both spiritually and rationally. These advantages are the main reason for customers to choose Islamic banks, in addition to their freedom from usury, for savings deposits, time deposits, demand deposits and other products. Customer who transacts with the Islamic bank could earn blessings, without having to pay attention to the service and trust, as the main reason to select Islamic banks as the bank of choice. Finally, Table 4 also shows the coefficient of determination, indicated by the value Negelkerke's $R^{2}$ of 0.364 . This finding 
implies that a combination of independent variables, namely characteristics of bank, services and trust, shari'ah compliance, and physical objects of bank were found to be able to explain the variation of the dependent variable, i.e., the customer decision to select the bank by $36.4 \%$, while the remaining $63.6 \%$ is explained by other variables which are not examined in this study, such as bank interest rate competitors, customer revenue, and understanding of religion.

\section{Conclusion}

This study empirically explored the pertinent factors, which customers and non-customers perceive as germane to their selection of Islamic bank in Aceh, Indonesia. A sample of 300 customers and non-customers of Bank Aceh Syariah, Brach Office of Sigli were selected based on the convenience sampling technique. Using the logistic regression technique, the study documented that the customers' selection of the banks were simultaneously influenced by the factors of banks' characteristic, services and trust, shari'ah compliance, and physical objects. Of these factors, banks' characteristic and shari'ah compliance were only found partially affecting the customers in their selection of Islamic bank in Aceh, Indonesia. Thus, these factors were documented to be the most pertinent factors perceived by the customers and non-customer to their selection of Islamic bank in Aceh, Indonesia. These findings imply that to attract more customers, the Islamic bank should enhance their unique characteristics and products' compliance. Additionally, this finding also implied that both factors of bank's characteristics and shariah compliance need to be a concern of bank's manager in decision-making by setting strategic steps to increase the number of customers with regard to these factors. Finally, the bank should be able to manage well the expectations of customers, especially in adopting the Islamic principles in its operation entirely. Should the bank enable to implement it, customers could be easily attracted to make Islamic bank as the bank of choice.

\section{References}

Abdelghani, E \& N.O. Oladokun. (2012). Malaysian Consumers' Preferences for Islamic Banking Attributes. International Journal of Social Economics. Vol. 39 (11): $859-874$.

Al-Ajmi, J. et.al. (2009). Clients of Conventional and Islamic Banks in Bahrain, how they choose which bank to patronise. International Journal of Social Economics. Vol. 36 (11): 1086-112.

Al Arif, M.N.R. (2012). Lembaga Keuangan Syariah: Kajian Teoritis Praktis. Bandung: Pustaka Setia 
Amin, M. \& Z. Isa. (2008). An Examination of The Relationship Between Service Quality Perception and Customer Satisfaction, a SEM approach towards Malaysian Islamic banking. International Journal of Islamic and Middle Eastern Finance and Management. Vol. 1(3): 191-209.

Dusuki, A.W. \& N.I. Abdullah. (2007). Why do Malaysian customers patronise Islamic banks? International Journal of Bank Marketing. Vol. 25 (3): 142-60.

Erol, C. \& R. El-Bdour. (1989). Attitudes, Behaviour and Patronage Factors of Bank Customers Towards Islamic Banks. International Journal of Bank Marketing. Vol. 7 (6): 31-47.

Hair, J. F. et.al. (1998). Multivariate Data Analysis. New Jersey: Prentice-Hall.

Haque, A. et.al. (2009). Factor influences selection of islamic banking: a study on malaysian customer preferences. American Journal of Applied Sciences. Vol. 6: 922-928.

Haron, S. et.al. (1994). Bank Patronage Factors of Muslim and Non-Muslim Customers. International Journal of Bank Marketing. Vol. 12 (1): 32-40.

Hassan, M. et.al. (2007). Banking Behaviour of Islamic Bank Customers in Bangladesh. Journal of Islamic Economics, Banking and Finance. Vol. 3 (2): 160-194.

Hidayat, H. et.al. (2015). Effects of Service Quality, Customer Trust and Customer Religious Commitment on Customer Satisfaction and Loyalty of Islamic Banks in East Java. Al-Iqtishad: Journal of Islamic Economics. Vol. 7 (2): 150-164.

Kamal, N. et.al. (1999). Islamic banking: a Study of Customer Satisfaction and Preferences in Jordan. International Journal of Bank Marketing. Vol. 17 (3): $135-151$.

Lateh, N. et.al. (2009). Customers' Perceptions on The Objectives, Characteristics and Selection Criteria of Islamic Bank in Thailand. Gadjah Mada International Journal of Business. Vol. 11 (2): 167-189.

Maski, G. (201). Analisis Keputusan Nasabah Menabung: Pendekatan Komponen dan Model Logistik Studi Pada Bank Syariah di Malang. Journal of Indonesia Applied Economics. Vol. 4 (1): 43-57.

Metawa, S. A. \& M. Almossawi. (1998). Banking behavior of Islamic Bank Customers: Perspectives and Implications. International Journal of Bank Marketing. Vol. 16 (7): 299-313.

Misbach, I. \& D. Hadiwidjojo. (2013). Islamic Bank Service Quality and Trust: Study on Islamic Bank in Makassar Indonesia. International Journal of Business and Management, 8(5), 48-62. 
Mohsin Butt, M. \& M. Aftab. (2013). Incorporating Attitude Towards Halal Banking in an Integrated Service Quality, Satisfaction, Trust and Loyalty Model in Online Islamic Banking Context. International Journal of Bank Marketing. Vol. 31 (1): 6-23.

Parasuraman, A. et.al. (1988). Servqual. Journal of retailing. Vol. 64 (1): 12-40.

Suryani \& Hendryadi. (2015). A developing model of relationship among service quality, consumer satisfaction, loyalty and word of mouth in Islamic banking. Al-Iqtishad: Journal of Islamic Economics,. Vol. 7 (1): 45-58.

Suryani. (2014). Analisis faktor kualitas pelayanan di Bank Syariah. Al-Iqtishad: Journal of Islamic Economics. Vol. 6 (2): 239-250.

Tjiptono, F. (2005). Pemasaran Jasa. Malang: Bayumedia Publising.

Walid, M. et.al. (2010). Islamic banking and customers' preferences: the case of the UK. Qualitative Research in Financial Markets. Vol. 2 (3): 185-199. 